\title{
PENDIRIAN BANK SAMPAH UIKA GUNA MENUMBUH KEMBANGKAN KEMANDIRIAN MAHASISWA MELALUI PENDEKATAN PROGRAM 3R
}

\author{
Afriansyah, Ari Awalulrahman, Ayu Lestari, M.Agil Al-munawar, Muhammad Ilham. \\ afryansyah49@gmail.com \\ Mahasiswa Fakultas Teknik
}

\begin{abstract}
ABSTRAK
Sampah selalu menimbulkan masalah hingga saat ini. Berbagai cara dilakukan untuk menanggulanginya. Mulai dari pembakaran sampah anorganik, pembuatan pupuk kompos dari sampah organik, dan daur ulang sampah. Pada umumnya, sebagian besar sampah yang dihasilkan di Indonesia merupakan sampah basah, yaitu mencakup 60-70\% dari total volume sampah. Bank sampah adalah suatu sistem pengolahan sampah kering secara kolektif yang mendorong masyarakat untuk berperan serta aktif di dalamnya. Sistem ini akan menampung, memilih, dan menyalurkan sampah bernilai ekonomi pada pasar sehingga masyarakat mendapat keuntungan ekonomi dari menabung sampah. bisa diperkirakan potensi pengelolaan sampah berbasis bisnis melalui daur ulang sampah (pemanfaatan kembali barang layak pakai), kerjasama dengan pengepul (menjual barang bekas yang tidak bisa diolah lagi), pembuatan kerajinan tangan yang diperjual belikan, serta pembuatan kompos.
\end{abstract}

Kata Kunci: Bank Sampah, Ekonomi, Potensi.

\section{PENDAHULUAN}

\section{Latar Belakang}

Sampah selalu menimbulkan masalah hingga saat ini. Berbagai cara dilakukan untuk menanggulanginya. Mulai dari pembakaran sampah anorganik, pembuatan pupuk kompos dari sampah organik, dan daur ulang sampah. Namun, masing-masing cara penanganan sampah tersebut mempunyai kelemahan dan terjadi kekurang optimalan dalam memanfaatkan produk hasil olahan sampah.

UIKA memiliki lebih dari 6000 mahasiswa aktif, 500 dosen dan karyawan, dan ratusan tamu atau stakeholder yang hilir mudik dikampus. Uika memiliki 6 fakultas. Selain itu, UIKA juga memiliki 2 kantin 1 koperasi dan beberapa warung jajanan. Kondisi ini membuat civitas yang sangat sibuk setiap harinya. Aktivitas yang terjadi menimbulkan efek positif dan negatif, salah satunya adalah timbulnya sampah. Berikut ini perkiraan volume timbunan sampah :

1. Sampah kertas $>10 \mathrm{~kg} / \mathrm{hari}$

2. Sampah plastik $>10 \mathrm{~kg} / \mathrm{hari}$

3. Sampah botol minuman $5 \mathrm{~kg} / \mathrm{hari}$

4. Sampah kardus $2-3 \mathrm{~kg} / \mathrm{hari}$

5. Sisa ATK $2-3 \mathrm{~kg} / \mathrm{hari}$

6. Sisa makanan $10 \mathrm{~kg} / \mathrm{hari}$

Dari data diatas bisa diperkirakan potensi pengelolaan sampah berbasis bisnis melalui daur ulang sampah (pemanfaatan kembali barang layak pakai), kerjasama dengan pengepul (menjual barang bekas yang tidak bisa diolah lagi), pembuatan kerajinan tangan yang diperjual belikan, serta pembuatan kompos. Untuk mendukung pengolahan sampah ini kampus UIKA diharapkan bisa mengeluarkan peraturan yang ditujukan ke sivitas akademika untuk ikut serta dalam daur ulang sampah.

Sisa makanan dibuang melalui pembuangan yang dibuat dekat kantin 
yang banyak pengunjung yang membuang sisa makanan. Kegunaan dari pembuangan sampah ini adalah mengurangi pencemaran lingkungan sekitar kampus Universitas Ibn Khaldun.

Dalam pengolahan sampah ada yang bisa diolah menjadi kompos yaitu sisa makanan, pengubahan sisa makanan menjadi kompos melalui beberapa tahap pengolahan, selain sisa makanan yang diubah menjadi kompos adapun kertaskertas atau ATK yang bisa dimanfaatkan kembali seperti kertas dijadikan amplop, dan ada banyak lagi pemanfaatan sampah yang bisa digunakan kembali.

\section{Sampah}

Sampah adalah suatu bahan yang terbuang atau dibuang dari sumber hasil aktifitas manusia maupun alam yang belum memiliki nilai ekonomis. Secara garis besar, sampah dibedakan menjadi dua jenis. Pertama, sampah anorganik (kering), contohnya adalah logam, besi, kaleng, plastik, karet, botol, dan lain-lain yang tidak dapat mengalami pembusukan secara alami. Kedua, sampah organik (basah), contohnya adalah sampah dapur, sampah restoran, sisa sayuran, rempah-rempah atau sisa buah dan lain-lain yang dapat mengalami pembusukan secara alami.

Pada umumnya, sebagian besar sampah yang dihasilkan di Indonesia merupakan sampah basah, yaitu mencakup $60-70 \%$ dari total volume sampah. Sampah merupakan konsekuensi dari adanya aktifitas manusia. Demikian juga dengan jenis sampah, sangat tergantung dari jenis material yang kita konsumsi.

\section{Bank Sampah}

Bank sampah adalah suatu sistem pengolahan sampah kering secara kolektif yang mendorong masyarakat untuk berperan serta aktif di dalamnya. Sistem ini akan menampung, memilih, dan menyalurkan sampah bernilai ekonomi pada pasar sehingga masyarakat mendapat keuntungan ekonomi dari menabung sampah.

Semua kegiatan dalam sistem bank sampah dilakukan dari, oleh, dan untuk masyarakat. Seperti halnya bank konvesnional, bank sampah juga memiliki sistem manajerial yang operasionalnya dilakukan oleh masyarakat. Bank sampah bahkan bisa juga memberikan manfaat ekonomi untuk masyarakat. Sampah yang disetorkan oleh nasabah sudah harus dipilah. Persyaratan ini mendorong masyarakat untuk memisahkan dan mengelompokkan sampah. Misalnya, berdasarkan jenis material: plastiik, kertas, kaca,dan metal. Jadi, bank sampah akan menciptakan budaya baru agar masyarakat mau memilah sampah. Dengan demikian, sistem bank sampah bisa dijadikan sebagai alat untuk melakukan rekayasa sosial. Sehingga terbentuk suatu tatanan atau sistem pengelolaan sampah yang lebih baik di masyarakat. 


\section{METODE PELAKSANAAN}

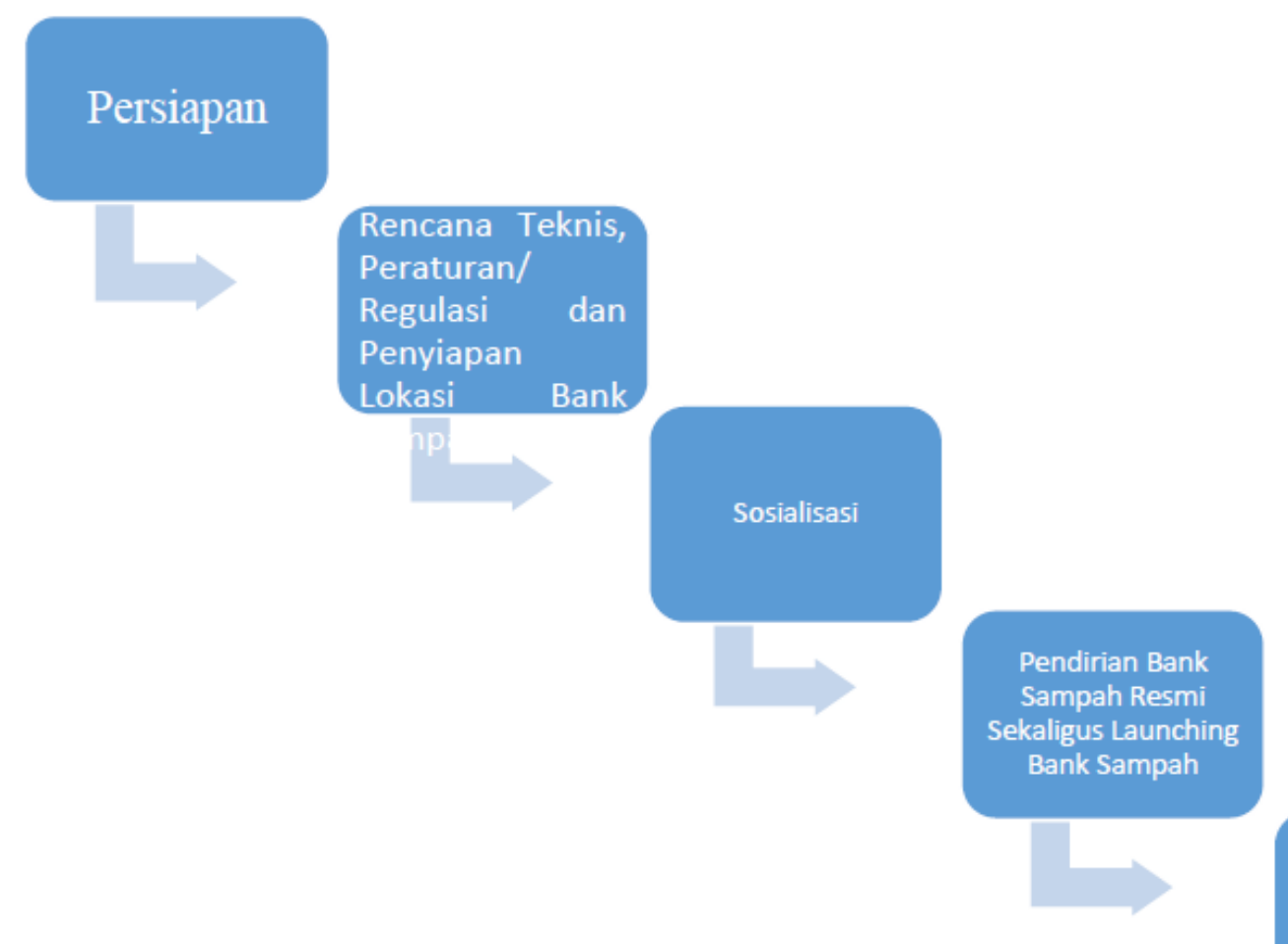

Persiapan

Bank sampah pada dasarnya adalah sebuah organisasi yang melibatkan banyak orang langkah awal dalam pendirian bank sampah adalah membentuk pengurus dari bank sampah.

Penyusunan Rencana Teknis, Peraturan/Regulasi dan Penyiapan Lokasi B ank Sampah.

Setelah melakukan persiapan langkah selanjutnya adalah dengan menyusun peraturan rencana teknis dan penyiapan lokasi bank sampah agar tetap diakui keberadaannya dan menyesuaikan dengan peraturan yang ada di Universitas Ibn Khaldun.

Penyiapan lokasi bank sampah

Dari persiapan dan penyusunan yang sudah dilakukan selanjutnya penyiapan lokasi bank sampah, yaitu mencari lokasi yang strategis dan mudah untuk bersosialisasi dengan mahasiswa UIKA mengenai adanya bank sampah.

\section{Sosialisasi}

Langkah selanjutnya adalah mensosialisasikan keberadaan bank sampah tersebut pada seluruh sivitas UIKA agar mereka tahu dan bisa berpartisipasi aktif dalam bank sampah yang telah didirikan.

Pendirian Bank Sampah Resmi Sekaligus Launching Bank Sampah

Setelah semua tahapan selesai, hanya tinggal peresmian dibukanya bank sampah tersebut dengan mengadakan peresmian sekaligus launching bank sampah agar bank sampah bisa berjalan semestinya.

\section{Pelaporan Rutin}

Setelah bank sampah berjalan sesuai dengan progres, lakukan pelaporan rutin keadaan bank sampah serta perkembangan bank sampah. 
BIAYA DAN JADWAL KEGIATAN

\begin{tabular}{|r|c|l|}
\hline No. & Jenis Pengeluaran & \multicolumn{1}{|c|}{ Biaya (Rp.) } \\
\hline 1 & Peralatan penunjang & Rp. 9.000 .000 \\
\hline 2 & Bahan habis pakai & Rp. 1.500 .000 \\
\hline 3 & Transportasi dan Akomodasi & Rp. 1.200 .000 \\
\hline 4 & Administrasi & Rp. 500.000 \\
\hline 5 & Lain-lain & Rp. 300.000 \\
\hline \multicolumn{2}{|r|}{} & Rp. 12.500 .000 \\
\hline
\end{tabular}

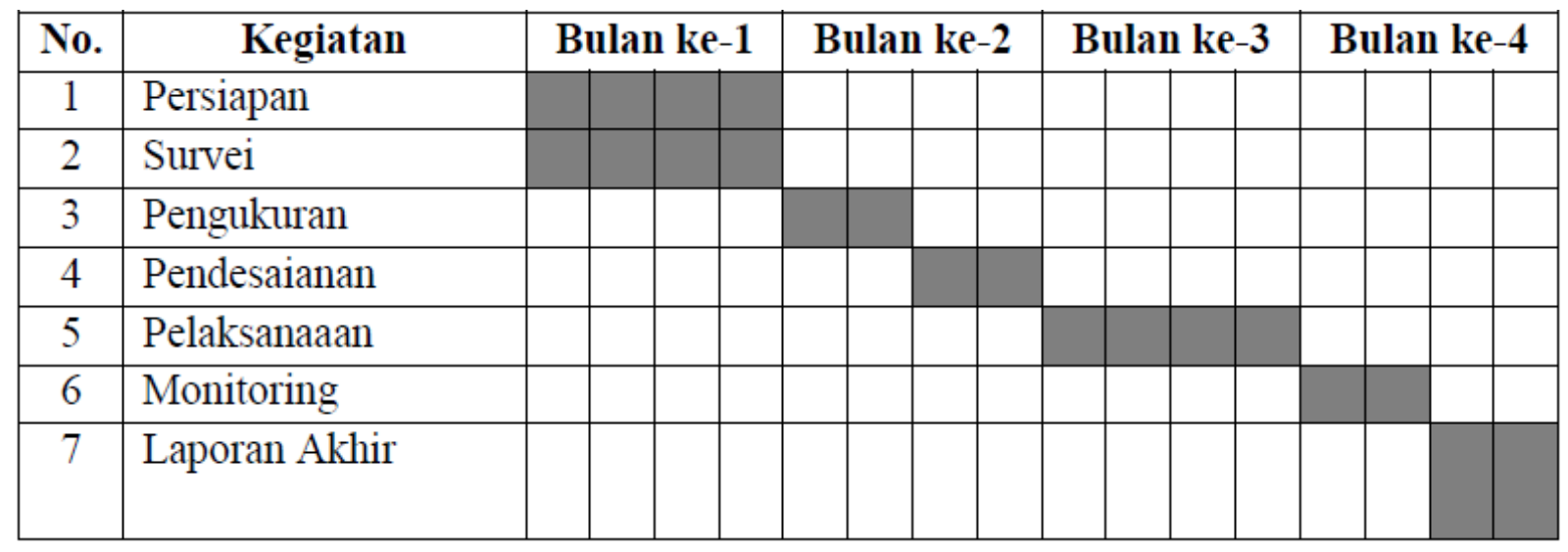

Jadwal kegiatan setiap pelaksanaan :
a) Hari Senin : Jam 13:00-14:20
b) Hari Rabu : Jam 13:00-14:20
c) Hari Jum'at : Jam 13:00-14:20 


\section{KESIMPULAN}

\section{Tujuan}

Tujuan penulisan karya tulis penelitian ini sebagai berikut :

1. Meningkatkan kepedulian mahasiswa dalam mengatasi sampah di UIKA.

2. Terciptanya kreatifitas mahasiswa untuk membuat kerajinan tangan yang terbuat dari sampah.

3. Mendapatkan konsep bank sampah yang ideal dan menarik bagi sivitas akademik UIKA.

\section{Manfaat}

a) Bagi mahasiswa :

i) Memberi informasi pemanfaatan sampah menjadi bahan bernilai.

ii) Mengurangi pencemaran udara dan tanah.

\section{REFERENSI}

Cecep Dani Sucipto, (2012), Teknologi Pengolahan Daur Ulang Sampah, Yogyakarta: Gosyen Publishing

Namara Idi. 2014 Kajian Pola Penanganan Pengolahan Sampah Kabupaten Sukabumi. Prosiding ATPW 2014 ITS Surabaya.

Sumaiku, Yohan. 2006. Akibat Pembakaran Sampah di Pekarangan Rumah Tangga dan Pembakaran b) Bagi pemerintah :

i) Dapat mengurangi lahan untuk tempat pembuangan sampah.

c) Bagi Kampus

i) Lingkungan menjadi bersih dan nyaman.

\section{Manfaat Kegiatan}

a) Menambah income bagi mahasiswa, sivitas akademika dan alumni.

b) Lingkungan menjadi bersih dan sehat.

c) Tumbuhnya jiwa Enterpreuneurship.
Hutan terhadap Kesehatan. (www.bppt.go.id. 14 April 2007).

Suprihatin, Agung, Dwi Prihanto dan Michel Gelbert.1996. Sampah dan Pengelolaannya. Malang: PPPGT / VEDC

Suwerda, Bambang (2012) Bank Sampah (Kajian Teori Dan Penerapan). Yogyakarta, CV. Rihama -Rohima. 